\title{
KOLABORASI GURU DALAM MGMP SEBAGAI PENINGKATAN MUTU PENDIDIKAN DI MTS UNGGULAN PONDOK PESANTREN AMANATUL UMMAH PACET MOJOKERTO
}

\author{
Oleh: \\ Afiyah Nur Kayati ${ }^{1}$ \\ Email: afiyah.kayati@trunojoyo.ac.id
}

\begin{abstract}
Inter-teacher collaboration is one program that can improve teacher competency releasing. Teacher collaboration activities are channeled in the subject teachers' consultative forum or MGMP. Most MGMP activities are carried out at the sub-district, city or district level. However, not all teachers in one school join MGMP forums in sub-districts, cities, or districts, resulting in competency gaps between teachers of one subject in a school. MGMP forums at the school level need to be encouraged and carried out more routinely than MGMP activities to improve teacher professionalism in improving the quality of education in schools. This research is a qualitative research. The process of data acquisition is done by in-depth interview techniques, observation, and documentation related to the MGMP teacher collaboration activities in the MTs Unggulan PP Amanatul Ummah and their impact on the quality of learning in the classroom. Based on the results of the study it can be revealed that there are three forms of MGMP work meeting activities in the MTs Unggulan PP Amanatul Ummah. The most effective form of activity is the MGMP meeting for each subject. The program activities carried out include routine programs and development programs. MGMP teacher collaboration activities affect the improvement of the quality of education which is reflected in the increase in teacher competency and professionalism as well as improving the quality of learning.
\end{abstract}

Keywords: collaboration, MGMP teachers, quality of education

\section{Pendahuluan}

Pembelajaran merupakan proses yang terjadi secara berkesinambungan yang melibatkan banyak pihak, seperti: guru, siswa, dan warga sekolah lainnya, untuk mencapai tujuan pembelajaran. Agar

${ }^{1}$ Dosen Universitas Trunojoyo Madura

Volume 11 Nomor 1 Maret 2020 
tujuan pembelajaran tercapai secara maksimal, semua warga sekolah harus menciptakan lingkungan belajar yang kondusif dan harmonis. Kondisi tersebut dapat dicapai dengan adanya kerja sama yang bagus antarwarga sekolah, seperti: kerja sama kepala sekolah dengan guru, guru dengan guru, guru dengan siswa, dan siswa dengan siswa. Salah satu faktor yang berperan dalam penciptaan lingkungan pembelajaran yang kondusif adalah guru. Hal tersebut dikarenakan gurulah yang membuat dan menyusun skenario pembelajaran.

Guru menjadi salah satu tonggak untuk mencapai tujuan pembelajaran yang akan menentukan kualitas atau mutu pendidikan di sekolah. Salah satu indikator mutu pendidkan dalam sebuah sekolah adalah bagaimana seorang guru mengembangkan kurikulum dan mengelola pembelajaran dengan baik. Hal tersebut senada dengan pendapat Sagala ${ }^{2}$ bahwa sebagai guru yang profesional, guru harus mengetahui dan menguasai tugas administrasi kurikulum dan pengembangannya serta pengelolaan peserta didik. Untuk mengembangkan sebuah kurikulum guru pun tidak dapat bekerja sendiri, tetapi harus adanya kerja sama dan kolaborasi dengan guru lain baik itu dengan guru satu mata pelajaran maupun dengan mata pelajaran lain. Kolaborasi aktif di antara para guru tersebut menjadi salah satu indikator keberhasilan program pengembangan profesional untuk mencapai tujuan bersama.

Para guru akan lebih berkompetensi dalam peningkatan kualitas pendidikan dalam sebuah sekolah jika mereka mengambil peran yang lebih aktif dalam mengembangkan metode kerja dan kurikulum serta melakukan kegiatan kolaborasi dengan guru lain dalam pendidikan. Selain itu, keaktifan guru dalam pengembangan kurikulum dan partisipasi dalam kegiatan kolaborasi dapat meningkatkan sistem pendidikan yang efisien dan produktif di sekolah. Guru pun akan terlibat aktif mendiskusikan gagasan yang mereka miliki dengan guru dan administrator lainnya. Hal

\section{8}

${ }^{2}$ Sagala, Syaiful. Konsep dan makna Pembelajaran. Bandung: Alfabeta. 2009. Hlm 
tersebut senada dengan pendapat Carrington dan Macarthur ${ }^{3}$ bahwa kolaborasi yaitu bekerja bersama untuk mencapai tujuan yang sama.

Kolaborasi antarguru pun menjadi salah satu program dalam kurikulum merdeka belajar. Hal tersebut dikarenakan dalam jangka panjang pembelajaran itu berbasis kolaborasi dan interaksi antara guru dengan guru. Guru mengajar guru merupakan salah satu cara meningkatkan relevansi kompetensi guru. Guru belajar dengan sesama guru dapat menumbuhkan empati dan kepercayaan pada sesama guru yang telah berperan dan bersinggungan dalam proses mengajar pada berbagai kelas. Selain itu, para guru akan mengetahui dan belajar tantangan mengajar pada kelas-kelas yang berbeda.

Carrington dan Macarthur4 mengungkapkan bahwa kolaborasi tidak seharusnya menggambarkan hirarki kekuatan, dimana pandangan salah satu orang dianggap lebih penting daripada yang lainnya, namun sebaliknya bahwa dalam kolaborasi memerlukan negosiasi dan konsultasi antarpartisipan. Dengan kegiatan berkolaborasi guru dapat membahas dan mencari solusi atas permasalahan yang terjadi di kelas. Selain itu, guru dapat saling bertukar pengalaman dalam melaksanakan pembelajaran di kelas.

Begitu pula dalam kaitannya dengan implementasi kurikulum yang membutuhkan kegiatan kolaborasi antarguru. Hal tersebut sesuai dengan pernyataan Mulyasa ${ }^{5}$ bahwa dalam rangka menyukseskan implementasi kurikulum dan menyiapkan guru sebagai fasilitator yang siap dalam pembelajaran perlu diadakan musyawarah antara kepala sekolah, guru, tenaga kependidikan, pengawas sekolah, dan komite. Kegiatan musyawarah tersebut diperlukan untuk menganalisis, mendiskusikan, dan memahami buku pedoman serta berbagai hal yang terkait dengan implementasi kurikulum sehingga tercipta pemahaman yang sama.

${ }^{3}$ Carrington dan Macarthur, Carrington, S. dan Macarthur, J. 2012. Teaching in Inclusive School Communities. Australia: John Willey \& Sons Australia. Hlm 216.

${ }^{4}$ Carrington dan Macarthur, Carrington, S. dan Macarthur, J. 2012. Teaching in Inclusive School Communities. Australia: John Willey \& Sons Australia. Hlm 216.

${ }^{5}$ Mulyasa, E.Pengembangan Implementasi Kurikulum 2013. Bandung: PT Remaja Rosdakarya. 2015. Hlm 44. 
Dengan demikian implementasi kurikulum dapat terlaksana secara berhasil sehingga dapat meningkatkan mutu pendidikan.

Kegiatan kolaborasi guru disalurkan dalam forum Musyawarah Guru Mata Pelajaran (MGMP). MGMP merupakan satu wadah asosiasi bagi guru mata pelajaran baik itu dalam lingkup sekolah, kabupaten, atau kota yang berfungsi sebagai wadah untuk saling berkomunikasi, belajar, bertukar pikiran, berbagi pengalaman dalam rangka meningkatkan kinerja guru sebagai praktisi pembelajaran di kelas. Tujuan umum penyelenggaraan MGMP adalah untuk mengembangkan kreativitas dan inovasi dalam meningkatkan profesionalitas guru. Sedangkan, tujuan khusus pelaksanaan MGMP antara lain memperluas wawasan dan pengetahuan guru mata pelajaran dalam upaya mewujudkan pembelajaran yang efektif dan efisien dan mengembangkan kultur kelas yang kondusif sebagai tempat pembelajaran yang menyenangkan, mengasyikkan, dan mencerdaskan siswa.

Banyak kegiatan yang dapat mendukung profesionalisme guru serta meningkatkan kualitas pembelajaran yang dapat dilakukan guru melalui forum MGMP. Kegiatan-kegiatan tersebut antara lain: penyamaan persepsi dan peningkatan pemahaman tentang kurikulum, pengembangan silabus dan sistem penilaian, pengembagan dan perancangan bahan ajar, pengembangan model pembelajaran efektif, pengembangan dan pelaksanaan analisis sarana pembelajaran yang tepat untuk menunjang pencapaian tujuan pembelajaran, pengembangan media pembelajaran, serta pengembangan dan pelaksanaan program pembelajaran yang berbasis teknologi ${ }^{6}$. Tidak hanya itu, dalam pertemuan MGMP pun dilakukan pembahasan tentang pemahaman materi dan pemantapan persiapan menghadapi ujian nasional.

Sebagian besar kegiatan MGMP ini dilakukan pada tingkatan kecamatan, kota, atau kabupaten. Namun, tidak semua guru dalam satu sekolah bergabung dalam forum MGMP kecamatan, kota, atau kabupaten

${ }^{6}$ Direktorat Peningkatan Profesi. Standar Pengembangan Kelompok Kerja Guru (KKG) Musyawarah Guru Mata Pelajaran (MGMP). Jakarta: Dikertorat Jenderal Peningkatan Mutu Pendidik dan Tenaga Kependidikan. 2008. Hlm 7. 
sehingga terjadi kesenjangan kompetensi antarguru satu mata pelajaran dalam sebuah sekolah. Pengurus MGMP pun tidak memiliki beban untuk mempertanggungjawabkan hasil pelaksanaan kegiatannya kepada sesama rekan guru, pimpinan sekolah, dan masyarakat. Selain itu, pertemuan MGMP yang berpindah-pindah tempat menjadi satu kendala bagi beberapa guru untuk hadir karena jarak tempat yang kurang terjangkau dari lokasi sekolah, waktu pelaksanaan, dan tugas lain guru di sekolah yang tidak bisa ditinggalkan untuk menghadiri pertemuan MGMP. Bahkan, banyak guru yang menolak berkolaborasi dan berinteraksi satu sama lain yang berbeda sekolah. Berdasarkan hal tersebut, forum MGMP di tingkat sekolah perlu digalakkan dan dilakukan lebih rutin daripada kegiatan MGMP tingkat kecamatan, kabupaten, atau kota.

Terdapat keunggulan tersendiri kegiatan MGMP di tingkat sekolah daripada kegiatan MGMP tingkat kecamatan, kabupaten, atau kota. Keunggulan tersebut antara lain para guru lebih intensif dan lebih bebas berbagi pikiran serta pengalaman tentang permasalahan yang terjadi pada siswa di sekolah tersebut. Selain itu, para guru dapat mengembangkan perangkat pembelajaran (silabus, RPP, bahan ajar, dan media) yang sesuai dengan karakteristik siswa di sekolah tersebut. Tidak hanya itu, guru-guru yang telah mengikuti pelatihan atau diklat dapat berbagi ilmu dengan guru lain yang tidak mengikuti. Bahkan, dalam forum MGMP di sekolah guru baru bisa mendapatkan pembimbingan dari guru yang telah lama mengajar dan lebih berpengalaman serta mereka akan lebih leluasa bertanya hal-hal yang belum mereka pahami karena dasar kedekatan emosi. Dengan pelaksanaan forum MGMP di sekolah tidak ada alasan bagi guru untuk tidak menghadiri kegiatan tersebut.

Salah satu sekolah yang telah melaksanakan kegiatan MGMP di tingkat sekolah secara rutin, yaitu MTs Unggulan Pondok Pesantren (PP) Amanatul Ummah Pacet Mojokerto. Forum pertemuan semua guru dengan kepala sekolah dilakukan setiap awal ajaran baru. Sementara, kegiatan MGMP dilakukan setiap dua sampai tiga bulan sekali atau ketika ada permasalahan dan informasi yang harus dibahas oleh guru MGMP bersama waka kurikulum. 
Berdasarkan uraian-uraian tersebut, kajian dalam tulisan ini, yaitu untuk mendeskripsikan efektivitas kolaborasi guru MGMP dalam peningkatan mutu pendidikan di MTs Unggulan PP Amanatul Ummah. Selain itu, dalam tulisan ini akan dideskripsikan bentuk-bentuk kolaborasi guru MGMP MTs Unggulan PP Amanatul Ummah dalam peningkatan kualitas pembelajaran.

\section{Metode Penelitian}

Penelitian ini merupakan penelitian kualitatif. Penelitian kualitatif digunakan karena data yang dihasilkan dalam tulisan ini bersifat deskriptif. Penelitian deskriptif menekankan pada kualitas suatu subjek yang diteliti. Penelitian deskriptif berusaha menelaah suatu fenomena yang terjadi di lingkungan untuk lebih memahami dan dapat menafsirkan dari fenomena yang diteliti.

Penelitian ini bertujuan untuk mendeskripsikan efektivitas kolaborasi guru MGMP dalam peningkatan mutu pendidikan pendidikan di MTs Unggulan PP Amanatul Ummah. Proses pemerolehan data dilakukan dengan teknik wawancara mendalam, observasi, dan dokumentasi terkait dengan kegiatan kolaborasi guru MGMP di MTs Unggulan PP Amanatul Ummah serta dampaknya terhadap kuaitas pembelajaran di kelas.

Subjek dalam penelitian ini, yaitu koordinator lembaga (kepala sekolah), waka kurikulum, dan guru MGMP yang diambil dua guru setiap mata pelajaran. Peneliti melakukan tanya jawab sambil membuat catatan untuk berjaga-jaga jika perekam mengalami kegagalan fungsi. Observasi dilakukan dengan mengamati kegiatan MGMP dan proses pembelajaran. Sedangkan, dokumentasi dilakukan dengan mengumpulkan, mengelompokkan, dan menganalisis dokumen-dokumen baik dokumen tertulis, gambar, maupun elektronik. Selanjutnya, data dianalisis dengan memahami, mensintesis, membandingkan dengan teori, dan selanjutnya menarik kesimpulan. 


\section{Hasil dan Pembahasan}

\section{A. Bentuk-bentuk Kegiatan Kolaborasi Guru MGMP MTs Unggulan PP Amanatul Ummah}

MTs Unggulan PP Amanatul Ummah secara rutin memiliki tiga kegiatan musyawarah atau rapat kerja guru. Kegiatan pertama yaitu kegiatan musyawarah guru atau rapat kerja yang diikuti oleh semua guru dari semua lembaga yang berada dalam naungan yayasan Amanatul Ummah dengan kepala sekolah dan pegurus yayasan. Kegiatan tersebut dilakukan setiap awal tahun ajaran baru. Hal-hal yang dibahas dalam rapat kerja tersebut antara lain kebijakan-kebijakan baik itu administratif maupun praktis terkait proses pembelajaran, evaluasi kegiatan pembelajaran dan pencapaian prestasi siswa selama satu tahun, permasalahan-permasalahan yang terjadi pada siswa, strategi-strategi atau metode dalam peningkatan kualitas pembelajaran, dan program kerja yang akan dijalankan selama satu tahun. Kegiatan tersebut tidak berjalan satu arah tetapi dua arah. Semua guru diberikan kesempatan untuk menyampaikan pikiran dan pengalaman yang dialami selama pembelajaran dan untuk peningkatan mutu pembelajaran. Selanjutnya, permasalahan-pemasalahan tersebut disikusikan bersama untuk dicarikan solusi terbaik.

Kegiatan yang kedua, yaitu musyawarah atau rapat kerja semua guru MTs Amanatul Ummah dengan koodinator lembaga (kepala sekolah) dan wakil kepala sekolah. Kegiatan tersebut pun dilakukan setiap awal semester baru. Hal-hal yang dibahas dalam kegiatan tersebut hampir sama dengan kegiatan rapat kerja yang dilakukan bersama pengurus yayasan. Namun, dalam kegiatan tersebut pembahasan lebih intensif tentang evaluasi program pembelajaran yang telah terlaksana dan programprogram sekolah baik terkait kegiatan akademik maupun non-akademik yang akan dijalankan selama satu tahun pelajaran. Permasalahan pembelajaran dan siswa dibahas tuntas dengan mencari solusi bersama antara guru dengan koordinator lembaga. Peran koordinator lembaga sebagai pemimpin memberikan pemikiran tentang solusi yang tepat dan 
penengah di antara perbedaan pendapat para guru serta pengambilan keputusan atas pemecahan atau solusi dari masalah yang dibahas. Hal tersebut searah dengan pendapat Mulyasa ${ }^{7}$ bahwa peran kepemimpinan kepala sekolah adalah mengoordinasikan, menggerakkan, dan menyelaraskan semua sumber daya pendidikan yang tersedia. Kepemimpinan kepala sekolah merupakan salah satu faktor penentu yang dapat menggerakkan semua sumber daya sekolah untuk dapat mewujudkan visi, misi, tujuan, dan sasaran sekolah melalui programprogram yang dilaksanakan secara terencana dan bertahap. Mulyasa ${ }^{8}$ berpendapat bahwa kepemimpinan kepala sekolah diperlukan untuk memobilisasi sumber daya sekolah dalam kaitannya dengan perencanaan dan evaluasi program sekolah, pembelajaran, dan pengelolaan ketenagaan.

Kegiatan lain yang dilakukan dalam rapat kerja semua guru di MTs Unggulan Amanatul Ummah adalah MGMP. Dalam MGMP tersebut, guru berkolaborasi untuk menyusun program tahuan dan program semester. Pembahasan tentang analisis kurikulum dan rencana penggunaan sumber belajar pun dilakukan. Kegiatan-kegiatan tersebut merupakan kegiatan rutin yang dilakukan pada setiap awal tahun pelajaran baru dan semester baru. Hal tersebut searah dengan pedoman kegiatan MGMP yang dikeluarkan oleh Direktorat Profesi Pendidik ${ }^{9}$ bahwa program rutin kegiatan MGMP diantaranya adalah penyusunan program semester dan analisis kurikulum.

Kegiatan yang ketiga adalah rapat MGMP tiap mata pelajaran yang dilakukan setiap dua sampai tiga bulan sekali. Kegiatan tersebut dilakukan pada awal semester, menjelang ujian tengah semester, dan menjelang ujian akhir semester. Kegiatan itu pun dilakukan pada saat kelompok MGMP tersebut tidak memiliki jam mengajar sehingga kegiatan tersebut tidak

\footnotetext{
${ }^{7}$ Mulyasa, E. Pengembangan Implementasi Kurikulum 2013. Bandung: PT Remaja Rosdakarya. 2015. Hlm 39.

${ }^{8}$ Mulyasa, E. Pengembangan Implementasi Kurikulum 2013. Bandung: PT Remaja Rosdakarya. 2015. Hlm 40.

${ }^{9}$ Direktorat Peningkatan Profesi. Standar Pengembangan Kelompok Kerja Guru (KKG) Musyawarah Guru Mata Pelajaran (MGMP). Jakarta: Dikertorat Jenderal Peningkatan Mutu Pendidik dan Tenaga Kependidikan. 2008. Hlm 7. 
akan mengganggu proses pembelajaran. Kegiatan yang dilakukan adalah jenis kegiatan program rutin dan program pengembangan.

Program rutin yang dilakukan dalam MGMP tersebut adalah diskusi pembahasan pembelajaran yang meliputi program-program yang akan dijalankan oleh kelompok guru MGMP, evaluasi program MGMP yang telah terlaksana, dan strategi atau model pembelajaran yang tepat untuk siswa pada kelas-kelas tertentu serta bertukar pendapat atau pengalaman tentang pembelajaran yang dilakukan oleh setiap guru termasuk permasalahan yang dihadapi. Dengan keterbukaan atau kepercayaan yang dimiliki oleh setiap anggota terhadap anggota lainnya, para guru akan saling belajar pengalaman dan tantangan mengajar pada kelas-kelas yang berbeda. Hal tersebut akan menumbuhkan peningkatan kreativitas guru untuk selalu berpikir mencari model atau stretegi yang tepat dalam pembelajaran.

Program lanjutan dari MGMP pada awal tahun ajaran baru pun dilakukan, seperti penyusunan silabus dan perencanaan pembelajaran atau RPP. Pada kegiatan tersebut semua anggota MGMP berperan aktif dalam kolaborasi atau kerja sama dalam penyusunan silabus dan RPP. Bentuk kolaborasi lain yang dilakukan tampak pada penyusunan instrumen evaluasi pembelajaran, yaitu soal evaluasi yang dibuat oleh salah satu guru akan dianalisis oleh anggota yang lain terkait materi dan bobot soal. Hal tersebut dikarenakan soal tersebut akan digunakan oleh semua guru MGMP untuk penilaian pada kelas-kelas yang mereka pada tingkatan kelas yang sama. Pembahasan tentang materi dan persiapan pemantapan ujian nasional untuk kelas tingkat atas pun dilakukan.

Program pengembangan yang dilakukan dalam kegiatan MGMP tersebut adalah penyusunan modul persiapan ujian nasional yang berisi ringkasan materi ujian nasional yang sesuai dengan standar kompetensi lulusan dan soal-soal latihan untuk persiapan ujin akhir sekolah maupun ujian nasional. Bentuk kolaborasi lain yang dilakukan oleh kelompok MGMP adalah melaksanakan program kerja sama antar guru untuk memecahkan masalah pembelajaran (lesson study). Program pengembangan lainnya adalah seminar kecil (pemaparan dan/atau 
pelatihan) hasil diklat atau workshop salah satu anggota kelompok MGMP kepada anggota yang lain atau kelompok MGMP lain.

Program rutin dan pengembangan dilakukan oleh semua kelompok MGMP MTs Unggulan PP Amanatul Ummah yang terdiri atas mata pelajaran Bahasa Indonesia, Matematika, IPA, IPS, Kewarganegaraan, Bahasa Inggris, Prakarya, Penjaskes, rumpun mata pelajaran agama, dan mulok (Bahasa Jawa dan Conversation). Hal tersebut searah dengan pedoman pelaksanaan MGMP dalam Standar Pengembangan KKG/MGMP10 bahwa program rutin dalam kegiatan MGMP antara lain diskusi permasalahan pembelajaran, penyusunan silabus dan RPP, analisis kurikulum, penyusunan instrumen evaluasi pembelajaran, dan pembahasan materi serta pemantapan persiapan ujian nasional. Sedangkan, program pengembangan yang dilakukan dalam forum MGMP antara lain penulisan karya, seminar, pendidikan dan pelatihan berjenjang, dan lesson study.

Forum diskusi MGMP yang dilakukan guru MTs Unggulan PP Amanatul Ummah bertujun untuk meningkatkan kualitas pembelajaran di kelas dan meningkatkan kompetensi guru. Hal tersebut searah dengan tujuan pelaksanaan MGMP yang terdapat pedoman pelaksanaan MGMP11 yaitu memperluas wawasan dan pengetahuan guru, memberi kesempatan kepada anggota kelompok untuk berbagi pengalaman serta saling memberikan bantuan dan umpan balik, meningkatkan mutu proses pendidikan dan pembelajaran, serta meningkatkan kompetensi guru.

Selain dalam bentuk rapat atau musyawarah MGMP, bentuk kolaborasi guru MGMP dapat terlihat dalam proses pembelajaran, yaitu adanya tim pengajar (team teaching). Bentuk tim pengajar tersebut tampak pada satu mata pelajaran pada satu kelas yang diampu oleh 2-3 guru. Dengan bentuk tersebut, guru akan bekerja sama dan berdiskusi secara

${ }^{10}$ Direktorat Peningkatan Profesi. Standar Pengembangan Kelompok Kerja Guru (KKG) Musyawarah Guru Mata Pelajaran (MGMP). Jakarta: Dikertorat Jenderal Peningkatan Mutu Pendidik dan Tenaga Kependidikan. 2008. Hlm 7.

${ }^{11}$ Direktorat Peningkatan Profesi. Standar Pengembangan Kelompok Kerja Guru (KKG) Musyawarah Guru Mata Pelajaran (MGMP). Jakarta: Dikertorat Jenderal Peningkatan Mutu Pendidik dan Tenaga Kependidikan. 2008. HIm 4 - 5. 
kontinu terkait proses pembelajaran, materi, penggunaan bahan ajar, dan penilaian. Selain itu, para guru yang tergabung dalam tim pengajar akan berdiskusi dan bekerja sama untuk mencari solusi atas permasalahan yang terjadi di kelas tersebut. Namun, sistem tim pengajar itu berlaku hanya untuk beberapa mata pelajaran saja.

\section{B. Efektivitas Kolaborasi Guru MGMP terhadap Peningkatan Mutu Pendidikan di MTs Ungguan PP Amanatul Ummah}

Kolaborasi guru MGMP dalam program rutin dan pengembangan berdampak pada pada peningkatan mutu pendidikan di MTs Unggulan PP Amanatul Ummah yang terlihat pada peningkatan kompetensi dan profesionalitas guru serta kualitas pembelajaran. Hal tersebut searah dengan pendapat Sanjaya ${ }^{12}$ bahwa beberapa kriteria dan variabel yang dapat mempengaruhi sistem pembelajaran adalah hasil belajar dan guru.

\section{Efektivitas Kolaborasi Guru MGMP terhadap Profesionalitas Guru MTs Unggulan PP Amanatul Ummah}

Kegiatan MGMP di tingkat sekolah yang dilakukan oleh guru MTS Unggulan PP Amanatul Ummah mendapatkan respons yang positif dari semua guru. Melalui kegiatan diskusi dalam forum MGMP, para guru dapat mengutarakan pemikiran untuk meningkatkan kualitas pembelajarannya di kelas dan permasalahan yang dihadapi dalam pembelajaran. Melalui forum diskusi dengan teman sejawat akan memberikan rasa percaya kepada sesama dan lebih leluasa untuk menceritakan permasalahan dan solusi yang ditemukan.

Selain kegiatan tersebut, forum MGMP MTs Amanatul Ummah juga sebagai tempat untuk berbagi ilmu. Anggota kelompok MGMP dapat berbagi ilmu hasil seminar atau pelatihan kepada teman anggota kelompok MGMP atau kelompok MGMP lain. Dengan belajar dari teman sesama guru, mereka dapat lebih mudah dan paham dengan yang disampaikan

${ }^{12}$ Sanjaya, Wina. Perencaaan dan Desain Sistem Pembelajaran. Jakarta: Kencana Prenada Media Group. 2012. Hlm 13 - 17. 
oleh temannya. Mereka pun tidak akan sungkan untuk bertanya jika mengalami kesulitan karena kedekatan emosi. Pembahasan mendalam pun masih dapat dilakukan di luar forum. Respons para guru lebih positif ketika mendapatkan materi, penjelasan, dan pelatihan dari teman sejawatnya karena gaya bahasa dan penyampaiannya yang tidak formal atau santai. Hal tersebut sesuai dengan pernyataan guru MGMP MTs Unggulan PP Amanatul Ummah berdasarkan hasil wawancara sebagai berikut.

"Mendengarkan penjelasan materi dari teman sendiri lebih mudah karena bisa langsung bertanya jika tidak paham." ${ }^{13}$

“Lebih mudah menerima materi dan lebih paham karena ada perbandingan pikiran juga, lebih tepatnya karena bahasanya yang tidak terlalu formal" 14

"Saya lebih mudah menerima materi karena penjelasannya juga secara santai, tidak sekaku ketika diberikan materi oleh pemateri luar." 15

Berdasarkan data wawancara tersebut dapat dilihat bahwa belajar dengan teman sejawat memiliki keunggulan daripada belajar dengan pemateri yang belum dikenal. Kegiatan tersebut merupakan bagian lesson study yang dapat meningkatkan kompetensi dan profesionalitas guru. Hal itu senada dengan pernyataan Nasir ${ }^{16}$ bahwa lesson study merupakan model pembinaan profesi melalui pengkajian pembelajaran secara kolaboratif dan berkelanjutan berdasarkan prinsip-prinsip kolegialitas dan mutual learning untuk membangun komunitas belajar.

Hal yang sama pun terjadi kepada guru-guru MGMP yang berlaku sebagai guru pemateri. Mereka memiliki rasa kebahagiaan dan kepuasan tersendiri dengan menyampaikan materi atau memberikan pelatihan

${ }^{13}$ Wawancara dengan guru OT

${ }^{14}$ Wawancara dengan guru LL

${ }^{15}$ Wawancara dengan guru NN

${ }^{16}$ Nasir, Mujiati, dan Asrul. 2019. Samaturu: Menstimulasi Spirit Kolaborasi Guru untuk Melaksanakan Lesson Study. Edum Journal. Vol. 2 No. 2 Tahun 2019 Halaman 126. 
kepada teman sejawat. Selain itu, mereka pun dapat mengembangkan keilmuannya dengan adanya pertanyaan dari peserta. Hal tersebut menunjukkan bahwa kegiatan berbagi ilmu dapat meningkatkan kompetensi dan profesionalisme guru. Hal tersebut terlihat pada data wawancara berikut.

"Alhamdulillah, semua teman-teman antusias, banyak yang bertanya tentang apa yang belum saya pikirkan sehingga kami memikirkan dan membahasnya bersama. Kegiatannya lebih kepada belajar bersama." 17

"Selama memberikan materi tidak ada kendala, terlihat temanteman guru sangat antusias, dan guru-guru aktif bertanya mana yang belum dimengerti" 18

Bentuk kolaborasi lain untuk meningkatkan kualitas proses pembelajaran adalah: kegiatan penyusunan silabus, RPP, bahan ajar, penilaian, dan modul pemantapan soal ujian nasional. Hal tersebut dibuktikan dengan penerbitan modul dauroh (pemantapan materi dan latihan soal ujian nasional) yang setiap MGMP setahun sekali diperbarui. Kegiatan kolaborasi itu akan lebih mendalam terutama bagi guru MGMP yang mengajar dengan sistem team teaching. Dengan sistem tersebut, guru akan bekerja sama melakukan sesuatu untuk mecapai tujuan yang sama dan menemukan solusi untuk memperbaiki kualitas pembelajaran.

Kegiatan-kegiatan kolaborasi guru MGMP tersebut dapat meningkatkan kompetensi dan profesionalitas seorang guru. Dengan kompetensi yang dimiliki seorang guru dapat mewujudkan sistem pembelajaran yang baik dan akan berdampak pada kualitas atau mutu pndidikan suatu sekolah. Hal itu sesuai dengan pernyataan Idi ${ }^{19}$ bahwa agar suatu proses pembelajaran berkualitas dan relevan dengan kebutuhan sumber daya manusia teraplikasi dengan baik, seorang pendidik

\footnotetext{
${ }^{17}$ Wawancara dengan guru NZ

${ }^{18}$ Wawancara dengan guru ID

${ }^{19}$ Idi, Abdullah dan HD, Safarina. Sosiologi Pendidikan: Individu, Masyarakat, dan
} Pendidikan. Jakarta: Rajawali Pers. 2014. Hlm 228. 
diharapkan dapat selalu melakukan introspeksi dan meningkatkan sejumlah kompetensi yang dimiliki dan memperhatikan tentang pentingnya profesionalisme dalam menjalankan tugasnya.

\section{Efektifitas Kolaborasi Guru MGMP terhadap Peningkatan Kualitas Pembelajaran di Kelas MTs Unggulan PP Amanatul Ummah}

Pembelajaran merupakan suatu sistem yang kompleks yang keberhasilannya dapat dilihat dari dua aspek, yaitu aspek produk dan aspek proses. Keberhasilan aspek proses adalah keberhasilan dalam proses pembelajaran. Sedangkan, keberhasilan aspek produk dapat dilihat dari hasil belajar siswa. Guru menjadi salah satu faktor dalam pencapaian keberhasilan dua aspek tersebut.

Dengan adanya kolaborasi guru MGMP, para guru dapat menemukan solusi atas permasalahan yang terjadi di kelas. Hal tersebut dibuktikan dengan guru-guru aktif sharing dan berdiskusi tentang permasalahan di kelas dan menemukan solusi itu secara bersama-sama dengan kelompok MGMP yang didampingi oleh waka kurikulum. Hal itu tampak pada pelajaran Bahasa Indonesia, yaitu cara untuk meningkatkan kemampuan literasi siswa dengan membiasakan siswa membaca buku bersama 10 menit sebelum pelajaran dimulai. Kegiatan tersebut dilakukan oleh semua guru MGMP Bahasa Indonesia.

Kegiatan kolaborasi guru MGMP tersebut akan membuka wawasan guru untuk terus berkembang dalam penyelesaian masalah-masalah pembelajaran. Hal itu searah dengan pernyataan Poerwati ${ }^{20}$ bahwa salah satu faktor yang menunjang keberhasilan belajar adalah dedikasi guru. Dedikasi itu akan berdampak pada peningkatan mutu pembelajaran yang efektif dan efisien. Di samping itu, ia berusaha mengarahkan anak didik untuk meraih pengetahuan, keterampilan, serta sikap.

Bentuk kolaborasi guru MGMP yang berpengaruh pada kualitas pembelajaran adalah pembahasan materi ujian nasional dan penyusunan modul latihan soal ujian nasional. Kegiatan kolaborasi itu akan berdampak

${ }^{20}$ Poerwati, Loeloek Endah dan Sofan Amri. Panduan Memahami Kurikulum 2013: Sebuah Inovasi Struktur Kurikulum Penunjang Masa Depan. Jakarta: PT Prestasi Pustakaraya.2013. Hlm 73. 
pada aspek produk, yaitu hasil belajar siswa. Sistem kelulusan pendidikan di Indonesia pada saat ini masih diukur dari keberhasilan siswa dalam menjawab soal-soal tes, seperti ujian nasional membuat guru untuk terus menganalisis dan melakukan pembahasan soal-soal ujian nasional secara bersama. Hal tersebut dimaksudkan agar tidak ada perbedaan jawaban atau persepsi antarguru yang akan menimbulkan kebingungan pada siswa. Dengan pembahasan soal tuntas dari guru siswa lebih mudah mengerjakan soal-soal dengan tipe yang sama. Hal tersebut dibuktikan dengan nilai try out siswa kelas IX yang selalu meningkat tiap minggunya. Begitu pula dengan nilai ujian nasional yang mendapatkan nilai rata-rata yang tinggi. Hal itu terbukti dengan nilai rata-rata ujian nasional siswa MTs Amanatul Ummah masuk 5 besar nilai tertinggi tingkat MTs se-Provinsi Jawa Timur pada tahun 2019.

Berdasarkan uraian-uraian di atas dapat dilihat bahwa kolaborasi guru MGMP berpengaruh pada peningkatan kualitas pembelajaran di kelas. Kualitas pembelajaran tersebut tampak pada kualitas proses dan produk pembelajaran. Guru selalu memikirkan inovasi baru untuk meningkatkan kualitas pembelajaran dengan saling bertukar pendapat dengan teman sejawat dalam kelompok guru MGMP yang akan berdampak pada hasil belajar siswa.

\section{Penutup}

MTs Unggulan PP Amanatul Ummah secara rutin memiliki 3 kegiatan musyawarah, yaitu: kegiatan rapat kerja yang diikuti oleh semua guru dari semua lembaga yang berada dalam naungan yayasan Amanatul Ummah dengan kepala sekolah dan pegurus yayasan, rapat kerja semua guru MTs Amanatul Ummah dengan koodinator lembaga (kepala sekolah) dan wakil kepala sekolah, dan rapat kerja kelompok guru MGMP tiap pelajaran. Kegiatan yang paling efektif adalah rapat kerja kelompok guru MGMP tiap pelajaran. Program kegiatan kolaborasi terdiri atas program rutin dan pengembangan yang meliputi diskusi permasalahan pembelajaran, penyusunan silabus dan RPP, analisis kurikulum, penyusunan instrumen evaluasi pembelajaran, dan pembahasan materi 
serta pemantapan persiapan ujian nasional, penyusunan modul, seminar, pendidikan dan pelatihan berjenjang, dan lesson study. Kegiatan kolaborasi guru MGMP berpengaruh terhadap peningkatan mutu pendidikan yang tercermin dengan peningkatan kompetensi dan profesionalitas guru serta peningkatan kualitas pembelajaran.

\section{DAFTAR RUJUKAN}

Carrington, S. dan Macarthur, J. 2012. Teaching in Inclusive School Communities. Australia: John Willey \& Sons Australia.

Direktorat Peningkatan Profesi. 2008. Standar Pengembangan Kelompok Kerja Guru (KKG) Musyawarah Guru Mata Pelajaran (MGMP). Jakarta: Dikertorat Jenderal Peningkatan Mutu Pendidik dan Tenaga Kependidikan.

Idi, Abdullah dan HD, Safarina. 2014. Sosiologi Pendidikan: Individu, Masyarakat, dan Pendidikan. Jakarta: Rajawali Pers.

Mulyasa, E. 2015. Pengembangan Implementasi Kurikulum 2013. Bandung: PT Remaja Rosdakarya.

Nasir, Mujiati, dan Asrul. 2019. Samaturu: Menstimulasi Spirit Kolaborasi Guru untuk Melaksanakan Lesson Study. Edum Journal. Vol. 2 No. 2 Tahun 2019 Halaman 126.

Poerwati, Loeloek Endah dan Sofan Amri. 2013. Panduan Memahami Kurikulum 2013: Sebuah Inovasi Struktur Kurikulum Penunjang Masa Depan. Jakarta: PT Prestasi Pustakaraya.

Sagala, Syaiful. 2009. Konsep dan makna Pembelajaran. Bandung: Alfabeta.

Sanjaya, Wina. 2012. Perencaaan dan Desain Sistem Pembelajaran. Jakarta: Kencana Prenada Media Group. 
SYAIKHUNA: Jurnal Pendidikan dan Pranata Islam p-ISSN:2086-9088, e-ISSN: 2623-0054 